\title{
The Expression Patterns of Some Pro-inflammatory and Anti-inflammatory Cytokines Genes Pre and Post Acute Exercise
}

\author{
Ehiaghe Friday Alfred ${ }^{1,2,3, \text { *, Onyenekwe Charles Chinedum }}{ }^{3}$, Ifeanyichukwu Martins ${ }^{3}$, \\ Akosile Christopher Olusanjo ${ }^{4}$, Ehiaghe Imuetiyan $\mathrm{Joy}^{2}$, Nancy Ibeh Chitogu ${ }^{3}$, \\ Ukibe Nkiruka Rose ${ }^{3}$, Osakue Nosa ${ }^{3}$, Ekpe Elijah Chukwuemeka ${ }^{3}$ \\ ${ }^{1}$ Department of Hematology, College of Health Sciences, Igbinedion University, Okada, Nigeria \\ ${ }^{2}$ Lahor Research and Medical Centre, Benin City, Nigeria \\ ${ }^{3}$ Department of Medical Laboratory Science, Nnamdi Azikiwe University, Awka, Nigeria \\ ${ }^{4}$ Department of Medical Rehabilitation, Nnamdi Azikiwe University, Awka, Nigeria
}

Email address:

fredleo2547@yahoo.com (E. F. Alfred)

${ }^{*}$ Corresponding author

\section{To cite this article:}

Ehiaghe Friday Alfred, Onyenekwe Charles Chinedum, Ifeanyichukwu Martins, Akosile Christopher Olusanjo, Ehiaghe Imuetiyan Joy, Nancy Ibeh Chitogu, Ukibe Nkiruka Rose, Osakue Nosa, Ekpe Elijah Chukwuemakal. The Expression Patterns of Some Pro-inflammatory and Anti-inflammatory Cytokines Genes Pre and Post Acute Exercise. International Journal of Immunology. Vol. 5, No. 4, 2017 , pp. 74-79. doi: $10.11648 /$ j.iji.20170504.13

Received: July 3, 2017; Accepted: July 18, 2017; Published: August 11, 2017

\begin{abstract}
This study was designed to determine the expression patterns of some pro-inflammatory and anti-inflammatory cytokine genes in some young male undergraduates that passed through exhaustive exercise using the Bruce protocol for submaximal acute exercise as studies have shown that exhaustive exercise activates the release of multiple cytokine genes which modulate the immune responses of stressed individuals. Twenty five (25) healthy young male undergraduates with an average age of $24.3 \pm 3$ years and body mass index of $22.7 \pm 1.8\left(\mathrm{Kg} / \mathrm{m}^{2}\right)$ participated fully in the study. Blood samples were collected from the participants before commencement of the study, at 1 hour, 4 hours and 24 hours post exercise. Tumor necrosis factor $\alpha$, interferon gamma and interleukin- 10 genes expression patterns were detected using reverse transcriptase polymerase chain reaction methods. Serum cortisol $(\mathrm{nmol} / \mathrm{L})$ using enzyme-linked immunosorbent assay method. The study revealed that eleven (11) out of the twenty-five (25) participants had their tumor necrosis factor $\alpha$ genes up-regulated at 1 hour post exercise and sustained till 24 hours post exercise. Moreover, interferon gamma and interleukin-10 genes were up-regulated at 4 hours post exercise and sustained till 24 hours post exercise in most of the subjects. This study also observed that the cortisol level of the exercised subjects was significantly higher at 1 hour post acute exercise when compared with pre-exercise stage. Acute exercise was associated with an enhanced lymphocytic cell functions which are evidence in the up-regulation patterns of both lymphocytic pro-inflammatory cytokine and anti-inflammatory cytokine genes post exercise.
\end{abstract}

Keywords: Tumor Necrosis Factor Alpha Genes, Exercise, Lymphocytic Cell Functions, Cytokines, Cortisol

\section{Introduction}

Post exercise stress has been reported to cause upregulation of several genes in the human body including lymphocytic genes which shows increased expression patterns within 1 to 4 hours after stimulation "[1], [2], [3], [4]". Several stressors including exercise-induced stress have been associated with a shift in cytokine production towards the anti-inflammatory patterns with cortisol and catecholamine elevations as the possible mediators [5]. It has been established that academic stress is inhibitory to the proliferation of $\mathrm{CD} 4^{+} \mathrm{T}$ lymphocytes with the elevation of serum cortisol as a possible mediator [6]. It has also been reported that academic stress significantly increases serum 
cortisol level of Nigerian students [7].

However, there is paucity of information on the expression patterns of pro-inflammatory and anti-inflammatory cytokine genes in exercise exhausted young male undergraduates. This study was designed to determine the expression patterns of some pro-inflammatory and anti-inflammatory cytokine genes in some young male undergraduates that passed through exhaustive exercise using the Bruce protocol for submaximal acute exercise as studies have shown that exhaustive exercise activates the release of multiple cytokine genes which modulate the immune responses of stressed individuals [4], [8]. This will add to the existing level of information on exercise which is beneficial.

\section{Materials and Methods}

\subsection{Subjects}

Twenty five (25) healthy young male undergraduate students with an average age of $24.3 \pm 3$ years and body mass index of $22.7 \pm 1.8\left(\mathrm{Kg} / \mathrm{m}^{2}\right)$ participated fully in the study. Patient consent was obtained from the subjects. The study was carried out in the Faculty of Health Science and Technology, Nnamdi Azikiwe University, Nnewi Campus.

\subsection{Inclusion Criteria}

This study was limited to apparently healthy young male undergraduate students of the Faculty of Health Sciences, Nnamdi Azikiwe University, Nnewi Campus within 18 and 35 years of age who are willing to participate in the study.

\subsection{Exclusion Criteria}

Young male with an underlying history of illness e.g. Hypertension, irregular heart rate, glucose utilization disorders, asthmatics, sickle cell anemia and other forms of anemia were excluded.

\subsection{Research Design}

The research design was an interrupted time series design.

\subsection{Study Design}

The subjects were encouraged to eat balance diet two hours prior to the endurance race and avoid any strenuous activity during the course of the research. Upon arrival at the venue of the research, their height $(\mathrm{H})$ and weight $(\mathrm{W})$ was measured and recorded and they were allowed to rest for at least ten minutes. The subjects were stressed to exhaustion using the Bruce treadmill protocol for sub maximal exercise. The exercise-induced stress protocol started at $2.7 \mathrm{~km} / \mathrm{hr}$ and a $10 \%$ grade and increased by $2 \%$ every 3 minutes in a steplike manner to a final stage at $9.6 \mathrm{~km} / \mathrm{hr}$ with a $22 \%$ grade as described by Vanessa and Elizabeth [9]. The target heart rate on the treadmill was $60-80$ percent of the heart rate maximal reserve (HRR). The difference between maximal heart rate (MHR) and resting heart rate (RHR).

The HRR was calculated using the formula:

\section{$H R R=M H R-R H R$.}

$\mathrm{MHR}=220$-age in years.

As described by Ogwumike et al [10]. The subjects continued this for twenty one minutes or get down when they are tired. Fourteen out twenty five subjects were exhausted before the twenty-one minutes. Blood sample was collected at four different time points: before, one hour, four hours and twenty four hours post exercise stages.

\subsection{Collection of Blood Samples}

Six milliliters of venous blood sample were collected from the medial cubital vein using vacutainer and needle from each of the subjects shared equally into plain containers and RNA gard vacutainer for total lymphocyte RNA isolation.

\subsection{Determination of Serum Cortisol Level}

Enzyme-linked immunosorbent assay was used in the determination of the level of serum cortisol in the serum as previously been described Ehiaghe et al [11]. In brief, $20 \mu 1$ of standard or sample (s) was added per microplates. $200 \mu \mathrm{l}$ cortisol hormone conjugate was added to the standard or sample (s) and covered with a sealing tape. It was incubated at room temperature for 1 hour. The solution was discarded and microplates washed three times with $300 \mu \mathrm{l}$ of $1 \mathrm{X}$ wash solution. $100 \mu \mathrm{l}$ of tetramethyl benzidine one step substrate was added to each micro plate and incubated for 15 minutes at room temperature in the dark with gentle shaking. $100 \mu$ l of stop solution was added to each micro plate. The intensity of the color developed was measured at $450 \mathrm{~nm}$ wavelength using stat $\operatorname{fax} \circledast 4700$ micro strip reader.

\subsection{Polymerase Chain Reaction Methods}

Total RNA was extracted using the ZR Whole -Blood RNA Mini Prep with catalog number R 1020 and R 1021 by ZYMO RESEARCH CORPORATION according to manufacturer's specification. The extracted Total RNA was retro-transcribed and amplified using One Taq One Step RT-PCR kit with catalog number NEB E $5315 \mathrm{~S}$ by NEW ENGLAND Bio Labs incorporation according to the manufacturer's specification. Selected primers were used to target cytokine genes using MJ research peltier thermal cycler polymerase chain reaction machine at the Lahor Research Laboratory and Medical Centre, 121, Old BeninAgbor Road, Benin City, Edo state, Nigeria. Table 1 shows details of the primers used. The system components were thaw and mixed by inverting ten times. The PCR was performed in a $50 \mu \mathrm{l}$ reaction mixture containing $25 \mu \mathrm{l}$ One Taq one-step reaction master mix $(2 x), 2 \mu 1$ One Taq one- step enzyme mix $(2 \mathrm{x}), 2 \mu \mathrm{l}$ of each gene-specific forward primer $(10 \mu \mathrm{M}), 2 \mu$ of each gene-specific reverse primer $(10 \mu \mathrm{M}), 9 \mu \mathrm{l}$ of nuclease-free water and $10 \mu \mathrm{l}$ of the RNA template (s) was added last. The PCR was started immediately as follows: Reverse transcriptase at $48^{\circ} \mathrm{C}$ for 
30 minutes, initial denaturation at $94{ }^{\text {"० }} \mathrm{C} "$ for 1 minute, followed by 39 cycles of denaturation at $94^{\circ} \mathrm{C}$ for 15 seconds, annealing at $\mathrm{TM}-5^{\circ} \mathrm{C}$ for 30 seconds, extension at $68^{\circ} \mathrm{C}$ for 1 minute. Five micro liters of the amplified PCR products were analyzed on $1 \%$ agarose gel containing ethidium bromide in $1 \mathrm{X}$ Tris EDTA buffer.
Electrophoresis was performed at $90 \mathrm{~V}$ for 30 minutes with the EDVOTEK tetra source electrophoresis machine, Bethesda, USA. The targeted genes were visualized by Wealtec Dolphin-Doc UV transilluminator and photographed. Molecular weights were calculated using molecular weight standard of the marker.

Table 1. Assay condition for each lymphocyte genes evaluated and purchased from Inqaba Biotechnology Industries, Hartfield, South Africa.

\begin{tabular}{lllll}
\hline Gene Symbol & Primers $\mathbf{5}^{\mathbf{1}} \mathbf{3}^{\mathbf{1}}$ (forward, reverse) & Molecular weight & Melting temperature (Tm) $\left({ }^{\circ} \mathbf{C}\right)$ & Gene bank accession number \\
\hline Tumor necrosis & TGTTGTAGCAAACCCTCAAGC & 6389.6 & 60.61 & 62.32 \\
factor- alpha & AGTCGGTCACCCTTCTCCA & 5699.4 & 63342 \\
Interleukin-10 & ATGCACAGCTCAGCACTGC & 5757.2 & 62.32 & 57.08 \\
Interferon & TCAGTTTCGTATCTTCATTGTC & 6657.3 & 58.35 & M 57627 \\
Gamma & TCTGCATCGTTTTGGGCT & 6096 & 62.57 & X 13274 \\
\hline
\end{tabular}

\subsection{Data Analysis}

All numerical results were analyzed with one-way ANOVA followed with post hoc multiple comparisons test using SPSS version 20.0 statistical program. P values $<0.05$ were considered significant.

\subsection{Ethics}

Ethical approval were obtained from the Ethics Committee of the Faculty of Health Science and Technology, Nnamdi Azikiwe University, Nnewi Campus and Lahor Research Laboratory and Medical centre in Benin City, Edo State, Nigeria with reference number LRL/ 005/014.

\section{Results}

The study revealed that eleven (11) out of the twenty-five (25) participants had their tumor necrosis factor $\alpha$ genes upregulated at 1 hour post exercise and sustained till 24 hours post exercise. Moreover, interferon gamma and interleukin10 genes were up-regulated at 4 hours post exercise and sustained till 24 hours post exercise in most of the subjects (Figure 1, 2 and 3) respectively. The study also revealed that the mean $\pm \mathrm{S}$. D of cortisol level of subjects who were exhausted before the end of the exercise bout (21 minutes) were $293.1 \pm 150.86 \mathrm{nmol} / \mathrm{L}$ pre-exercise, $411.0 \pm 169.71$ $\mathrm{nmol} / \mathrm{L}$ one hour post exercise, $246.0 \pm 155.12 \mathrm{nmol} / \mathrm{L}$ four hours post exercise and $183.4 \pm 72.83 \mathrm{nmol} / \mathrm{L}$ twenty-four hours post exercise. The cortisol level were significantly higher at one hour post exercise when compared with preexercise $(\mathrm{P}=0.000)$. However, there was no significant difference when compared with the four and twenty-four hours post exercise $(\mathrm{P}=0.222)$. The mean $\pm \mathrm{S}$. D of cortisol level of subjects who were exhausted at twenty-one minutes of the exercise bout were $226.4 \pm 67.95 \mathrm{nmol} / \mathrm{L}$ preexercise, $355.6 \pm 153.62 \mathrm{nmol} / \mathrm{L}$ one hour post exercise, $190.1 \pm 64.05 \mathrm{nmol} / \mathrm{L}$ four hours post exercise and $183.6 \pm$ $58.11 \mathrm{nmol} / \mathrm{L}$ twenty-four hours post exercise. The cortisol level were significantly higher at one hour post exercise when compared with pre exercise $(P=0.000)$. Similarly, there was no significant difference when compared with the four hours post exercise ( $\mathrm{P}=0.494)$ and twenty-four hours post exercise $(\mathrm{P}=0.420)$ (Table 2$)$.

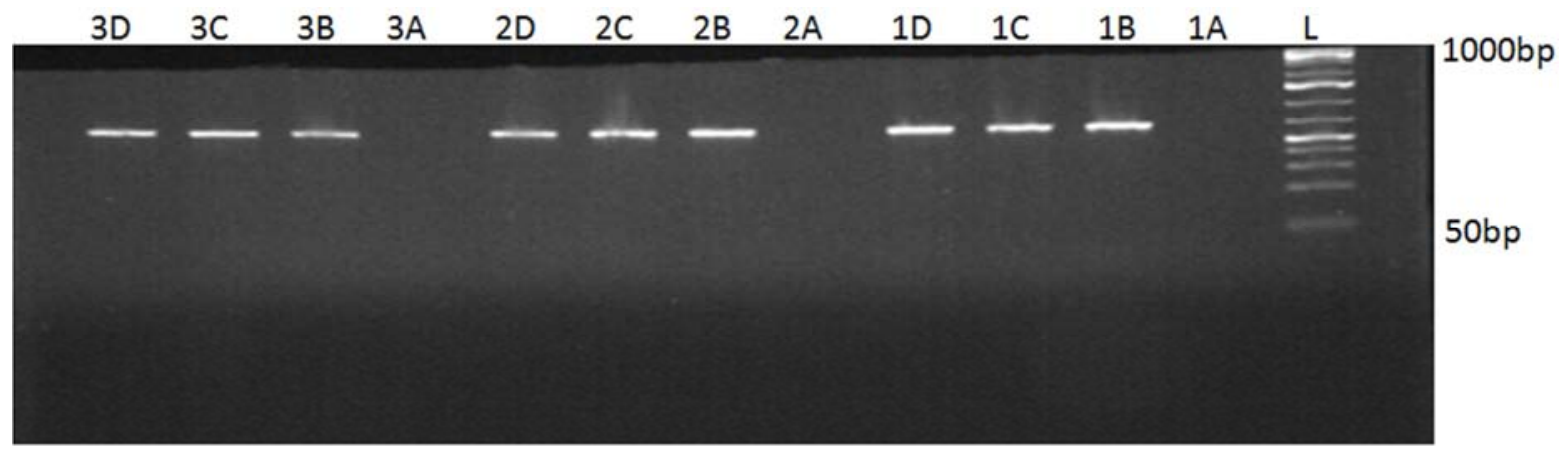

Figure 1. A sample of the reverse transcriptase PCR results for tumor necrosis factor alpha genes analyzed on a $1.0 \%$ agarose gel electrophoresis stained with ethidium bromide. L is a $50 \mathrm{bp}-1000 \mathrm{bp}$ DNA ladder (molecular marker). Lanes $1 \mathrm{~B}, 1 \mathrm{C}, 1 \mathrm{D}, 2 \mathrm{~B}, 2 \mathrm{C}, 2 \mathrm{D}, 3 \mathrm{~B}, 3 \mathrm{C}$ and $3 \mathrm{D}$ are positive bands for the expressed tumor necrosis factor alpha genes at $300 \mathrm{bp}$ from the exercised subjects 1 - 3. Lanes $1 \mathrm{~A}, 2 \mathrm{~A}$ and $3 \mathrm{~A}$ are negative bands from the pre stage of the exercise.

Keys:

$\mathrm{A}=$ pre-exercise

$\mathrm{B}=1$-hour post exercise

$\mathrm{C}=4$-hours post exercise

$\mathrm{D}=24$-hours post exercise 


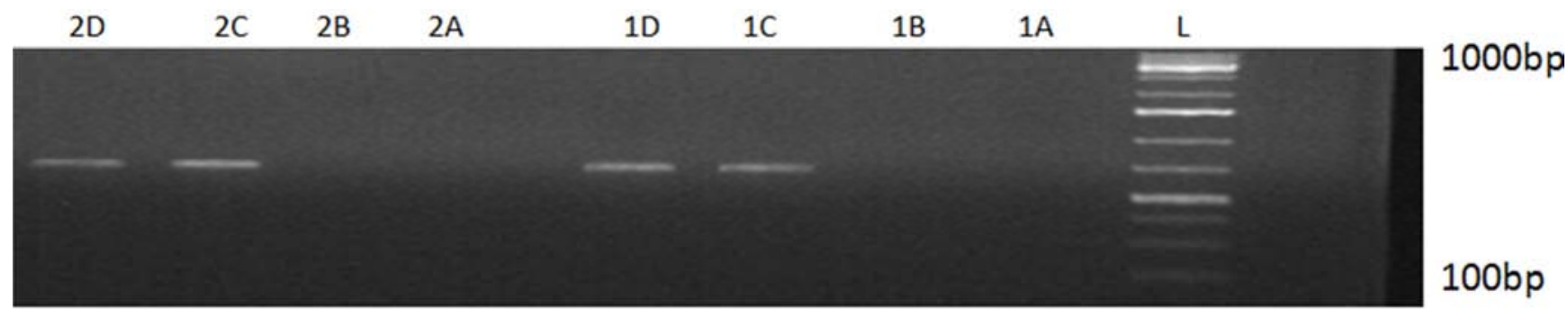

Figure 2. A sample of the reverse transcriptase PCR results for interferon gamma genes analyzed on a 1.0\% agarose gel electrophoresis stained with ethidium bromide. $L$ is a $100 \mathrm{bp}-1000 \mathrm{bp}$ DNA ladder (molecular marker). Lanes $1 \mathrm{C}, 1 \mathrm{D}, 2 \mathrm{C}$ and $2 \mathrm{D}$ are positive bands for the expressed interferon gamma genes at $375 \mathrm{bp}$ from the exercised subjects. Lanes $1 \mathrm{~A}, 1 \mathrm{~B}, 2 \mathrm{~A}$ and $2 \mathrm{~B}$ are negative bands from the pre stage and 1 hour post exercise respectively.

Keys:

A $=$ pre-exercise

$\mathrm{B}=1$-hour post exercise

$\mathrm{C}=$ 4-hours post exercise

$\mathrm{D}=24$-hours post exercise

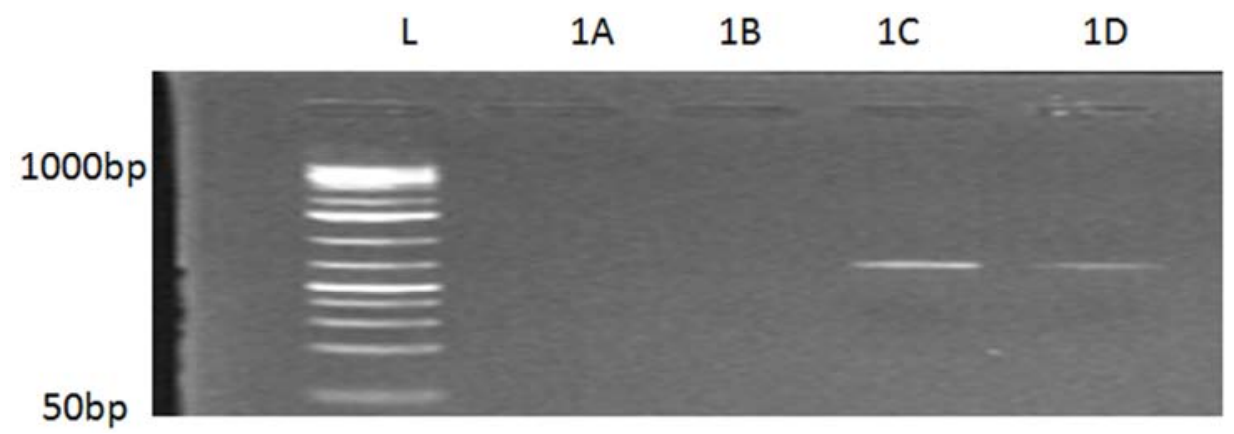

Figure 3. A sample of the reverse transcriptase PCR results for interleukin 10 genes analyzed on a $1.0 \%$ agarose gel electrophoresis stained with ethidium bromide. $L$ is a $50 \mathrm{bp}-1000 \mathrm{bp}$ DNA ladder (molecular marker). Lanes $1 \mathrm{C}$ and $1 \mathrm{D}$ are positive bands for the expressed interleukin 10 genes at $250 \mathrm{bp}$ from the exercised subject. Lanes $1 A$ and $1 B$ are negative bands from the pre stage and 1 hour post exercise.

$\mathrm{A}=$ pre-exercise

$\mathrm{B}=1$-hour post exercise

$\mathrm{C}=$ 4-hours post exercise

$\mathrm{D}=$ 24-hours post exercise

Table 2. Level (mean $\pm S D)$ of cortisol (nmol/L) in exercised participants.

\begin{tabular}{|c|c|c|}
\hline \multirow{2}{*}{ Time intervals } & \multicolumn{2}{|l|}{ Cortisol level } \\
\hline & Subjects exhausted before 21 minutes $(n=14)$ & Subjects exhausted at 21 minutes $(n=11)$ \\
\hline Pre-exercise (A) & $293.1 \pm 150.86$ & $226.4 \pm 67.95$ \\
\hline 1 hour post exercise (B) & $411.0 \pm 169.71$ & $355.6 \pm 153.62$ \\
\hline 4 hours post exercise (C) & $246.0 \pm 155.12$ & $190.1 \pm 64.05$ \\
\hline 24 hours post exercise (D) & $183.4 \pm 72.83$ & $183.6 \pm 58.11$ \\
\hline F Value & 6.032 & \\
\hline P Value & $0.000^{*}$ & \\
\hline A vs. B & $0.013 *$ & $0.016^{*}$ \\
\hline A vs. C & $0.316(\mathrm{~ns})$ & $0.494(\mathrm{~ns})$ \\
\hline A vs. D & $0.222(\mathrm{~ns})$ & $0.420(\mathrm{~ns})$ \\
\hline
\end{tabular}

Keys:

$<21=$ exhaustion before 21 minutes

$21=$ exhaustion at 21 minutes

ns $=$ non-significant

$*=$ significant

\section{Discussion}

This study was designed to determine the expression patterns of some pro-inflammatory and anti-inflammatory cytokine genes in some young male undergraduates that passed through exhaustive exercise using the Bruce protocol for sub-maximal acute exercise. The target heart rate on the treadmill was $60-80$ percent of the heart rate reserve. It was interesting to note that eleven (11) out of the twenty-five participants had their tumor necrosis factor $\alpha$ genes upregulated at 1 hour post exercise and sustained till 24 hours post exercise. Moreover, interleukin-10 and interferon 
gamma genes were up-regulated at 4 hours post exercise and sustained till 24 hours post exercise in most of the subjects.

This study also observed that the cortisol level of the exercised subjects was significantly higher at 1 hour post acute exercise (approximately 9:30 am) when compared with pre-exercise stage (approximately 8:30 am). These results support the fact that stress of any origin, whether physical or mental can greatly enhance the secretion of cortisol. It has been reported that elevated cortisol inhibits the action of insulin thereby encouraging higher blood glucose level via gluconeogenesis and glycogenolysis [12]. However, there was a significant decrease of cortisol level at 4 hour post acute exercise (approximately 1: $30 \mathrm{pm}$ ) and 24 hours post acute exercise (approximately 8: $30 \mathrm{am}$ ) when compared with the pre exercise (approximately 8: $30 \mathrm{am}$ ). The significant decrease in cortisol level could be attributed to a restored homeostasis as the subjects feel relieved of the stress induced by the acute exercise bout.

The delayed expression of the lymphocyte interferon gamma and interleukin-10 genes in the studied population calls for concern. It further indicates that there may be other regulatory factors that may be protecting the expression of these genes. Post-exercise stress was associated with an enhanced lymphocytic cell functions which are evidence in the up-regulation patterns of both lymphocytic proinflammatory cytokine genes (tumor necrosis factor $\alpha$ and interferon gamma genes) and anti-inflammatory cytokine gene (interleukin-10 gene).

The possible mechanism of the up-regulation of the lymphocytic gene expression patterns observed in this study could be linked to adenosine triphosphate depletion, accumulation of adenosine diphosphate, and adenosine monophosphate due to consumption of adenosine triphosphate by the exercising muscles [13]. Studies have shown that post exercise stress induces the release of tumor necrosis factor alpha genes which enhances the production of multiple cytokines during exhaustive exercise "[14], [15], [16]", whereas Ambarish et al. [17] observed that post exercise elevation of interferon gamma acts as a positive feedback mechanism on the leukocytes by enhancing their ability to produce additional cytokines such as tumor necrosis factor alpha, and interleukin-10 during muscle contractions. It had been reported that post exercise stress enhances the up-regulation of interleukin-10 genes which in turn inhibits the production of TNF- $\alpha$ and IFN- $\gamma$ in attempt to regain cellular homeostasis during muscle contractions "[18], [19], [20]".

The up-regulatory patterns of these lymphocytic genes are of diagnostic importance in establishing evidences of stress as the immune responses to stress are characterized by leukocytes infiltration and production of multiple cytokines genes within the blood and contracting muscle cells [4]. Thus, these lymphocytic gene expression patterns might be predicting the patterns of stress of individuals exposed to stressors. In terms of directions for future research, these ideas seem worthy of further investigation. In light of the fact that sub-maximal acute exercise using the Bruce protocol did not impair the lymphocytic cell functions in vivo, this model may be an ideal form of exercise to improve health and performance without overstressing the lymphocytic cell functions.

\section{Conclusion}

Acute exercise was associated with an enhanced lymphocytic cell functions which are evidence in the upregulation patterns of both lymphocytic pro-inflammatory cytokine and anti-inflammatory cytokine genes post exercise. Acute exercise enhances the release of cortisol, and interleukin-10 genes to reinstate homeostasis via the modulation of the immunological responses to stress. Acute exercise should be undertaken with caution to prevent over activation of the immune responses during and post exercise.

\section{References}

[1] Abdalla AO, Kiaii S, Hansson L, Rossmann ED, JeddiTehrani M, Shokri F, Osterborg A, Mellstedt H, Rabbani H. Kinetics of cytokine gene expression in human CD 4+ and CD $8+$ lymphocyte subsets using quantitative real-time PCR. Scandinavian Journal of Immunology. 2003; 58: 601- 606.

[2] Katia C, Michela F, Stefano C, Giacomo S, Maurizio SAV. Exercise induced stress in horses: Selection of the most stable reference genes for quantitative RT-PCR normalization. $B M C$ Molecular Biology. 2008; 9: 49-51.

[3] Bermudez DM, Canning DA, Liechty KN. Age and proinflammatory cytokine production: Wound-healing implications for scar-formation and the timing of genital surgery in boys. Journal of Pediatric Urology. 2011; 7: 324- 331.

[4] Josef F. Biomarkers of peripheral muscle fatigue during exercise. Musculoskeletal Disorders. 2012; 13: 213- 218.

[5] Elenkor IJ and Chrousos E. Stress hormones, proinflammatory and anti-inflammatory Cytokines and autoimmunity. Annals of Academic Science. 2002; 966:290-303.

[6] Ehiaghe FA, Agbonlahor DE, Ositadima MI, Ehiaghe IJ, Osadolor HB. Effect of academic stress on serum cortisol and CD 4 cell count in young male post graduate students in Okada, Nigeria. International Journal of Biological and Chemical Sciences. 2014; 8: 1249-1253.

[7] Onyenekwe CC, Ezeani MC, Udeogu AN, Anyiam CD, Melude US, Nnadozie O. Effect of pre and post Academic Examination stress on serum level of cortisol and progesterone circulation amongst students of Nnamdii Azikiwe University Nnewi Campus, Anambra state, Nigeria. International Journal of Tropical Disease and Health. 2012; 4: 62- 69 .

[8] Golzari Z, Shabkhiz F, Soudi S, Kordi MR, Hashemi SM. Combined exercise training increase IFN gamma and reduce IL-12 level in the plasma and supernatant of peripheral blood mononuclear cell in women. International Immunopharmacology Journal. 2010; 10: 1415- 1419.

[9] Vanessa N and Elizabeth D. Submaximal exercise testing: Clinical application and interpretation. Journal of the American Physical Therapy Association. 2000; 80: 782- 807. 
[10] Ogwumike OO, Arowojolu AO, Sanya AO. Effects of a 12week endurance exercise program on adiposity and flexibility of Nigerian perimenopausal and postmenopausal women. Nigerian Journal of Physiology Sciences. 2011; 26: 199- 206.

[11] Ehiaghe FA, Ehiaghe IJ, Igere EB, Iyen IR. The effects of aqueous extracts of Acalypha wilkesiana supplementation and exercise training on hematopoietic system in rats. American Journal of Plant Science. 2013; 4: 1834- 1838.

[12] Carl $\mathrm{AB}$ and Edward RA. Tietz fundamental of clinical chemistry $5^{\text {th }}$ edition. Saunder, Philadelphia, Pennsylvania. 2006; PP. 432- 437.

[13] Pedersen BK. American Physiological Society. Comprehensive Physiology. 2013; 3:1337-1362.

[14] Denguezli-Bouzgarrou M, Ben-Jabrallah M, Gaid S, Slama F, Ben-Saad H, Tabka Z. Effects of brief maximal exercise on interleukin -6 and tumor necrosis factor alpha. Biology of Sport. 2006; 23: 3-15.

[15] Flaster H, Bernhagen J, Calandra T, Bucala R. The
Macrophage Migration Inhibitory Factor-Glucocorticoid Dyad: Regulation of Inflammation and Immunity. Molecular Endocrinology. 2007; 21 (6): 1267-1280.

[16] Xiao W, Chen P, Dong J. Effect of overtraining on skeletal muscle growth and gene expression. International Journal of Sports Medicine. 2012; 33: 846- 853.

[17] Ambarish V and Radhika K. Alteration of interferon gamma in Human plasma with graded physical activity. Journal of Clinical Diagnosis. 2014; 8: 5- 7.

[18] Bente KP. The anti-inflammatory effect of exercise: its role in diabetes and cardiovascular disease control. The Biochemical Society. 2006; 42: 105- 117.

[19] Rodrigo T, Silvia AC, Veronica SP, Patricia MLD. Effect of exercise on the immune sytem: response, adapation and cell signaling. Exercise and Sport Science. 2012; 18: 34- 49.

[20] Evans WJ and Cannon JG. The metabolic effects of exerciseinduced muscle damage. Exercise and Sport Sciences Reviews. 1991; 19:99-125. 